\title{
Disposal of Plasma Heme in Normal Man and Patients with Intravascular Hemolysis
}

\author{
David A. Sears \\ From the Department of Medicine, University of Rochester School of Medicine \\ and Dentistry, Rochester, New York 14620
}

A в S T R A C T The clearance of plasma protein-bound heme, its sites of removal, and the reutilization of hemeiron were studied by radioisotopic techniques in normal human subjects and in patients with intravascular hemolysis.

In normal subjects, injected heme $-{ }^{\mathrm{s0}} \mathrm{Fe}$ was bound immediately by albumin and the $\beta_{1}$-globulin, hemopexin. Its clearance from the plasma was descr bed by a single exponential equation, and the half-life in plasma was $7-8 \mathrm{hr}$. Removal was largely by the liver. Iron reutilization began promptly, and half the injected heme-iron was incorporated into circulating red cells within one cell life-span.

In patients with intravascular hemolysis, hemopexin was depleted, and injected heme was bound solely to albumin. Plasma clearance was described by a double exponential equation of the form: $y=\mathrm{Ae}^{-\mathrm{k}_{1} \mathbf{t}}+\mathrm{Be}^{-\mathrm{k}_{2} \mathbf{t}}$. The half-lives of the two components averaged 3.9 and 22.2 $\mathrm{hr}$, respectively. Removal was by the liver in at least some of the patients, and iron reutilization was variable, depending on the state of body iron stores. When hemopex $n$ was depleted in a normal subject by repeated heme injection, clearance mimicked that observed in the patients.

\section{INTRODUCTION}

The presence of nonhemoglobin heme in the plasma of patients with intravascular hemolysis was recognized by Schumm in 1912 (2), and he described the simple spectrophotometric test bearing his name which is still a useful clinical tool (3). Subsequently Heilmeyer suggested that plasma heme exists in protein-bound form

Some of this work has been presented elsewhere in abstract form (1).

Dr. Sears' present address is the Department of Physiology and Medicine, University of Texas Medical School at San Antonio, 7703 Floyd Curl Drive, San Antonio, Tex. 78229.

Received for publication 14 April 1969 and in revised form 10 August 1969.
(4), and Fairley characterized the heme-albumin complex or methemalbumin $(5,6)$. Methemalbumin is commonly the predominant heme pigment in the plasma of patients with chronic intravascular hemolysis $(7,8)$. Its detection as a late sign of a previous acute episode of hemolysis, as after a hemolytic transfusion reaction, has been clinically useful (9). In recent years, a second plasma protein capable of binding heme firmly has been characterized (10), and the role of this $\beta_{1}$-globulin, hemopexin, in hemolyt.c disease has been partially defined (11-14).

The clearance kinetics and organ sites of removal of plasma hemoglobin have been studied by a number of investigators (15-19), and the reutilization of hemoglobiniron characterized (20). Little is known, however, of the early steps in the catabolism of plasma heme. Animal studies have been performed in rhesus monkeys (21), rats (22), and rabbits (23), but human studies have not been reported. Since the binding affinities of various plasma proteins for heme are different in animals and man $(24,25)$, extrapolation of the results of animal studies to man may not be justified.

The present investigations have been carried out to assess the clearance of plasma protein-bound heme, its site(s) of removal, and the reutilization of its iron in normal human subjects and in patients with chronic intravascular hemolysis.

\section{METHODS}

Preparation and administration of hematin ${ }^{1}$ and collection of samples. Nonradioactive recrystallized hemin was obtained commercially. ${ }^{2}$ Hemin- ${ }^{50} \mathrm{Fe}$ was prepared in rabbits.

\footnotetext{
1 The terminology applied to various forms of heme may be confusing. In this paper hemin refers to the form crystallized from acid, that is ferric protoporphyrin chloride. In alkaline solution, it is hematin or ferric protoporphyrin hydroxide. Heme is used for protein-bound forms or as a general designation.

${ }^{2}$ Eastman Organic Chemicals, Rochester, N. Y.
} 
Sufficient sodium citrate was added to ${ }^{50} \mathrm{FeCl}_{3}{ }^{3}$ in $0.5 \mathrm{~N} \mathrm{HCl}$ to produce a citrate: iron molar ratio of $2: 1$. Rabbits were given intravenous doses of this ${ }^{50} \mathrm{Fe}$ solution on two successive days and bled $10-17$ days later. Hemin $-{ }^{50} \mathrm{Fe}$ was isolated from the blood by the method of Labbe and Nishida (26) and was recrystallized at least once. The specific activity was not changed significantly by a second recrystallization.

Appropriate amounts of nonradioactive and hemin ${ }^{50} \mathrm{Fe}$ were weighed out, sterilized in an autoclave, and dissolved at a concentration of $10 \mathrm{mg} / \mathrm{ml}$ in sterile $0.1 \mathrm{M}$ sodium carbonate immediately before use. This hematin solution was administered to the study subjects intravenously over a 1-2 min period. The total hematin dose, determined by weighing the syringe before and after injection, varied between 0.77 and $1.23 \mathrm{mg} / \mathrm{kg}$ body weight and the total dose of ${ }^{80} \mathrm{Fe}$ between 7.2 and $11.8 \mu \mathrm{c}$. In study 8 , the normal subject was given daily intravenous injections of nonradioactive hematin, approximately $1 \mathrm{mg} / \mathrm{kg}$, for the 7 days before the study to deplete plasma hemopexin as was reported previously (27). Blood samples were drawn $15 \mathrm{~min}$ after injection and at intervals thereafter; the early samples were taken from the arm opposite that used for the injection. Venipunctures were done carefully to minimize artifactual hemolysis. The blood, anticoagulated with 1-2 $\mathrm{U}$ of heparin $/ \mathrm{ml}$, was centrifuged immediately and the plasma frozen for later studies. Urine was collected for 5-10 hr after injection in studies 1-3 and for $24 \mathrm{hr}$. in the rest of the studies. Aliquots were stored at $4^{\circ} \mathrm{C}$.

Plasma and urinary heme pigment studies. Total plasma heme pigment was determined by the modified benzidine method (28) using $0.1 \mathrm{M}$ sodium chloride for dilutions (29). Hemoglobin standards, determined with each set of samples, were prepared from stroma-free red cell hemolysates which had been dialyzed thoroughly against $0.1 \mathrm{M}$ sodium chloride. Hemoglobin concentration in the standard solution was determined by the cyanmethemoglobin method (30). All heme pigment concentrations are expressed in terms of hemoglobin unless otherwise stated. Individual heme-proteins were separated by electrophoresis on cellulose polyacetate strips in a horizontal cell." In the normal subjects, samples of plasma were run at $300 \mathrm{v}$ for $1 \mathrm{hr}$ in $0.025 \mathrm{M}$ barbital buffer, $\mathrm{pH}$ 8.6. A maximum of three heme-protein bands could be identified: hemopexin-heme closest to the origin, then haptoglobin-hemoglobin which was present in small amounts in normal plasma, and finally methemalbumin in the most anodal position. Free hemoglobin which migrates like hemopexin-heme under these conditions was, of course, not present. In the plasma of the patients with intravascular hemolysis, free hemoglobin was frequently present. Therefore, electrophoresis was carried out at $175 \mathrm{v}$ for $1 \mathrm{hr}$ in $0.05 \mathrm{M}$ phosphate buffer, $\mathrm{pH}$ 7.0. Under these conditions three heme-proteins could also be separated. In this case free hemoglobin was closest to the origin, then hemopexin-heme when present, and finally methemalbumin closest to the anode. Haptoglobin was absent from the patients' plasmas, so the similar migration of haptoglobin-hemoglobin and hemopexin-heme in the phosphate buffer was of no concern. The strips were stained with $o$-dianisidine ${ }^{5}$ and hydrogen peroxide and scanned in a recording densitometer as previously described (13). Examples of stained electrophoretic strips are shown in Fig. 1. Haptoglobin levels were determined

${ }^{3}$ Obtained from Tracerlab, Waltham, Mass. and Nuclear Science and Engineering Corp., Pittsburgh, $\mathrm{Pa}$.

- Gelman Instrument Company, Ann Arbor, Mich.

s 3,3'-dimethoxybenzidine, Eastman Organic Chemicals.

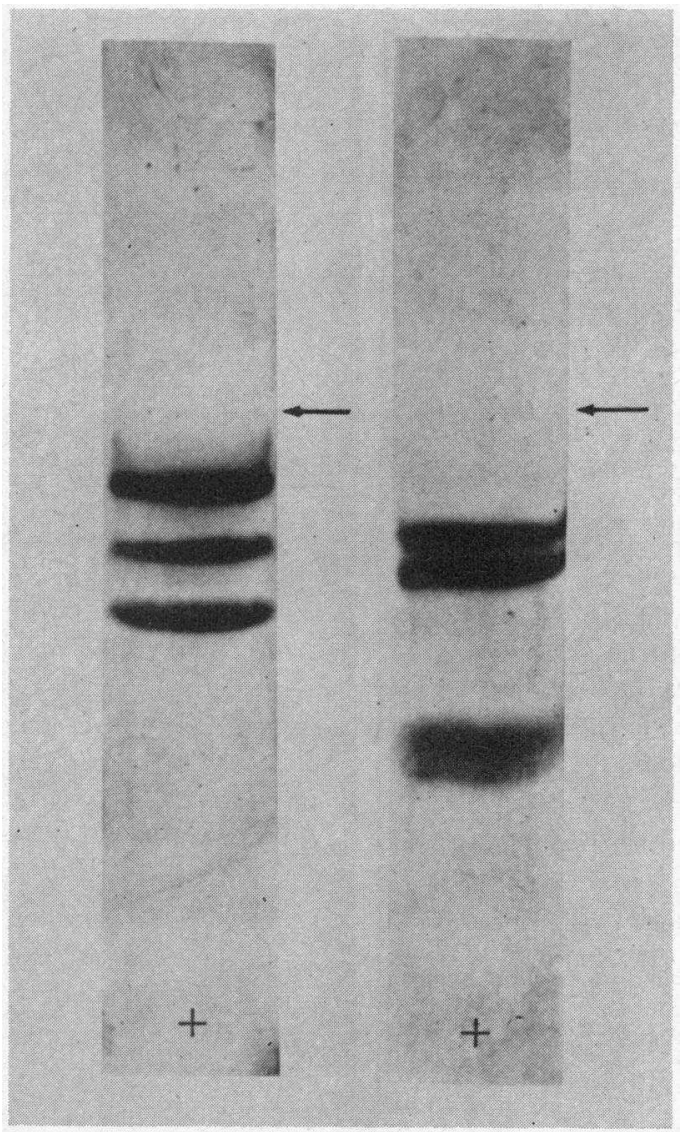

FIGURE 1 Cellulose polyacetate electrophoretic strips stained for heme pigments with $o$-dianisidine. The arrows indicate the point of application of the plasma, the + signs the anodal ends of the strips. The left-hand strip was run in phosphate buffer, $\mathrm{pH} 7.0$, and the bands, starting from the point of application, are: free hemoglobin, hemopexin-heme, and methemalbumin. The right-hand strip was run in barbital buffer, $\mathrm{pH} 8.6$, and the bands, starting from the point of application, are: hemopexin heme, haptoglobin-hemoglobin, and methemalbumin.

by electrophoresis after incubation of plasma with known amounts of hemoglobin (31). Plasma hemopexin levels were assessed by two methods (13). (a) An aliquot of plasma was incubated with sufficient hematin, dissolved in $0.1 \mathrm{M}$ sodium carbonate, to raise the plasma heme pigment level by $40-50 \mathrm{mg} / 100 \mathrm{ml}$. The plasma was subjected to electrophoresis and the amount of added hematin bound to hemopexin determined. In normals, hematin bound to hemopexin under these conditions averaged $8.6 \mathrm{mg}$ (expressed as hemoglobin) $/ 100 \mathrm{ml}$ plasma. (b) Serial dilutions of plasma were subjected to double diffusion in agar gel against rabbit anti-human hemopexin. ${ }^{\circ}$ The highest dilution producing a precipitin line was designated the "plasma hemopexin titer." Titers in normal plasma are 1:128 or greater. Urinary heme pigment was determined by a slight modification (32) of the benzidine method of Crosby and Furth (28).

${ }^{\circ}$ Obtained from Certified Blood Donor Service, Woodbury, N. Y. 
Mcasurcment of blood and urine radioactivity. Radioactivity was measured in a well counter ${ }^{7}$ for sufficient time to reduce counting error to $1 \%$ in most cases. In studies $1-4$ red cell radioactivity was determined by counting packed cells which had been washed three times wit.1 saline to remove all plasma, and the counts were corrected for the saline content of the packed cell column as determined by the microhematocrit. In studies 5-8 whole blood and plasma were counted, the microhematocrit was measured, and red cell radioactivity was calculated. In studies 1-3 aliquots of unconcentrated urine were counted; in studies 4-8, 30-50 $\mathrm{ml}$ of each urine sample were concentrated by evaporation to a volume of approximately $3 \mathrm{ml}$ for counting. For all calclilations, counts were corrected for isotope decay to the time of injection which was considered zero time.

Since the decline in plasma radioactivity was used to follow plasma heme clearance, it was necessary to know whether transferrin-bound ${ }^{50} \mathrm{Fe}$ made a significant contribution to plasma radioactivity during the period of clearance of heme ${ }^{50} \mathrm{Fe}$. Therefore in each study, $1 \mathrm{ml}$ aliquots of radioactive plasma samples were dialyzed for 3 days at $4^{\circ} \mathrm{C}$ against buffer containing $0.1 \mathrm{M}$ ethylenediaminetetraacetate (EDTA) and $0.1 \mathrm{~m}$ sodium acetate with the $\mathrm{pH}$ adjusted from 5.5 to 5.6 with acetic acid. Preliminary experiments had confirmed the findings of Hosain, Marsaglia, and Finch (33) that transferrin-iron was fully dialyzable under these conditions, while all iron in hematin added to plasma and bound to protein remained in the dialysis bag. In no case was a significant amount of the plasma radioactivity lost during dialysis against the EDTA-sodium acetate buffer, as compared with controls simultaneously dialyzed against phosphate-buffered saline, $\mathrm{pH}$ 7.4. Therefore, for all calculations, plasma radioactivity was considered entirely due to heme $-{ }^{50} \mathrm{Fe}$.

To ascertain whether heme bound to albumin would exchange with the heme of free hemoglobin existing in the plasma of some of the patients studied, aliquots of plasma from subject 4 were incubated with hematin- ${ }^{50} \mathrm{Fe}$ for $1 \mathrm{hr}$ and for $24 \mathrm{hr}$ at $37^{\circ} \mathrm{C}$. The plasma was then subjected to paper electrophoresis in $0.05 \mathrm{M}$ phosphate buffer, $\mathrm{pH} 7.0$, for $22 \mathrm{hr}$ at $120 \mathrm{v}$. Free hemoglobin and methemalbumin bands, identified by staining with benzidine-hydrogen peroxide, were cut out and their radioactivity determined. These were the only heme-pigments present in the plasma since haptoglobin and hemopexin were depleted. In one experiment, additional oxyhemoglobin was incubated with the piasma as well as the hematin ${ }^{50} \mathrm{Fe}$. In every case all the radioactivity was in the methemalbumin band, and none was detectable in the hemoglobin band or elsewhere on the electrophoretic strip. Bunn and Jandl have shown that heme exchange between globin and albumin occurs only when the heme-iron is in the ferric state (34), and Rabiner, Helbert, Lopas, and Friedman have demonstrated that human hemoglobin is not oxidized to methemoglobin when it circulates in the plasma of a dog (35). Thus, in these studies, it was assumed that injected heme- ${ }^{50} \mathrm{Fe}$ bound to albumin did not exchange with hemoglobin-l:eme to a significant extent.

Body surface counting. Radioactivity over the heart, liver, spleen, and sacrum was determined 30-60 min after injection of the hematin ${ }^{50} \mathrm{Fe}$ at frequent intervals for the first $24 \mathrm{hr}$, and then at increasing intervals for a period of

${ }^{7}$ Model 200-S, Radiation Instrument Development Laboratory, Skokie, Ill., for studies 1-5 and 8; Model 4233, Nuclear-Chicago Corporation, Des Plaines, Ill. for studies 6 and 7. at least 20 days. $^{8}$ The probe was centered as follows: heart, third intercostal space at the left sternal border; liver, right mid-clavicular line about $3 \mathrm{~cm}$ above the right costal margin; spleen, left mid-clavicular line at the left costal margin; and sacrum, midline over the upper portion. The subject was supine for the heart, liver, and spleen counts and prone for the sacrum count. Two 1-min counts were taken at each site and the mean value used for calculation after subtraction of background, which was counted for at least $10 \mathrm{~min}$, and correction for isotope decay.

Mathematical analysis. Simple exponential curves for heme clearance in studies $1-3$ on normal subjects were fitted by the least squares method (36). Analyses of the plasma clearance curves in studies 4.8 on subjects with hemopexin depletion were performed using the standard nonlinear least squares method (37), utilizing an IBM 360-44 computer.

Other methods. To calculate plasma volume, the total counts per minute in the administered hematin- ${ }^{50} \mathrm{Fe}$ were divided by the value for plasma counts per minute obtained from extrapolation of the plasma ${ }^{50} \mathrm{Fe}$ disappearance curve to zero time. Red cell mass was calculated from the plasma volume and the whole body hematocrit ( 0.92 times the venous hematocrit). Total incorporation of ${ }^{50} \mathrm{Fe}$ into circulating red cells was calculated from the red cell mass and and measured red cell radioactivity.

Plasma bilirubin concentrations were determined by a modification of the method of Malloy and Evelyn (38).

Serum iron and iron-binding capacity were determined by a modification of the method of Young and Hicks (39).

Routine hematological tests were performed by standard methods (40).

\section{RESULTS}

Table I shows base line hematological and plasma heme pigment data in the normal subjects and patients.

Normal subjects (studies 1-3). Hematin $-{ }^{69} \mathrm{Fe}$ injected intravenously was immediately bound to hemopexin and albumin. In all three studies both complexes were still identifiable in the plasma by electrophoresis $19 \mathrm{hr}$ after injection. In each case the plasma sample taken 22-23 hr after injection showed only small amounts of hemopexin-heme, and methemalbumin was no longer detectable. Clearance from the plasma approximated a firstorder process with half-lives of $7.7,8.1$, and $7.2 \mathrm{hr}$, respectively in the three studies (Fig. 2).

The results of body surface counting in study 1 are shown in Fig. 3. The data in studies 2 and 3 were qualitatively very similar. There was a rapid decline of

${ }^{8}$ For studies $1-3$ a model DS-100 shielded uncollimated probe with a 1 inch sodium iodide crystal connected to a model $161 \mathrm{~A}$ scaler was used, for the other studies a model 821330 shielded collimated probe with a 2 inch sodium iodide crystal connected to a model 8700 scaler, all from NuclearChicago Corporation.

' In study 4 , the patient was transfused 2 days and 6 days after hematin ${ }^{50} \mathrm{Fe}$ injection. The initial red cell mass was therefore multiplied for each subsequent calculation by the ratio of current to original hematocrit. Even a large error introduced by this admittedly crude calculation would not affect the interpretation of the data for red cell incorporation of ${ }^{50} \mathrm{Fe}$. 


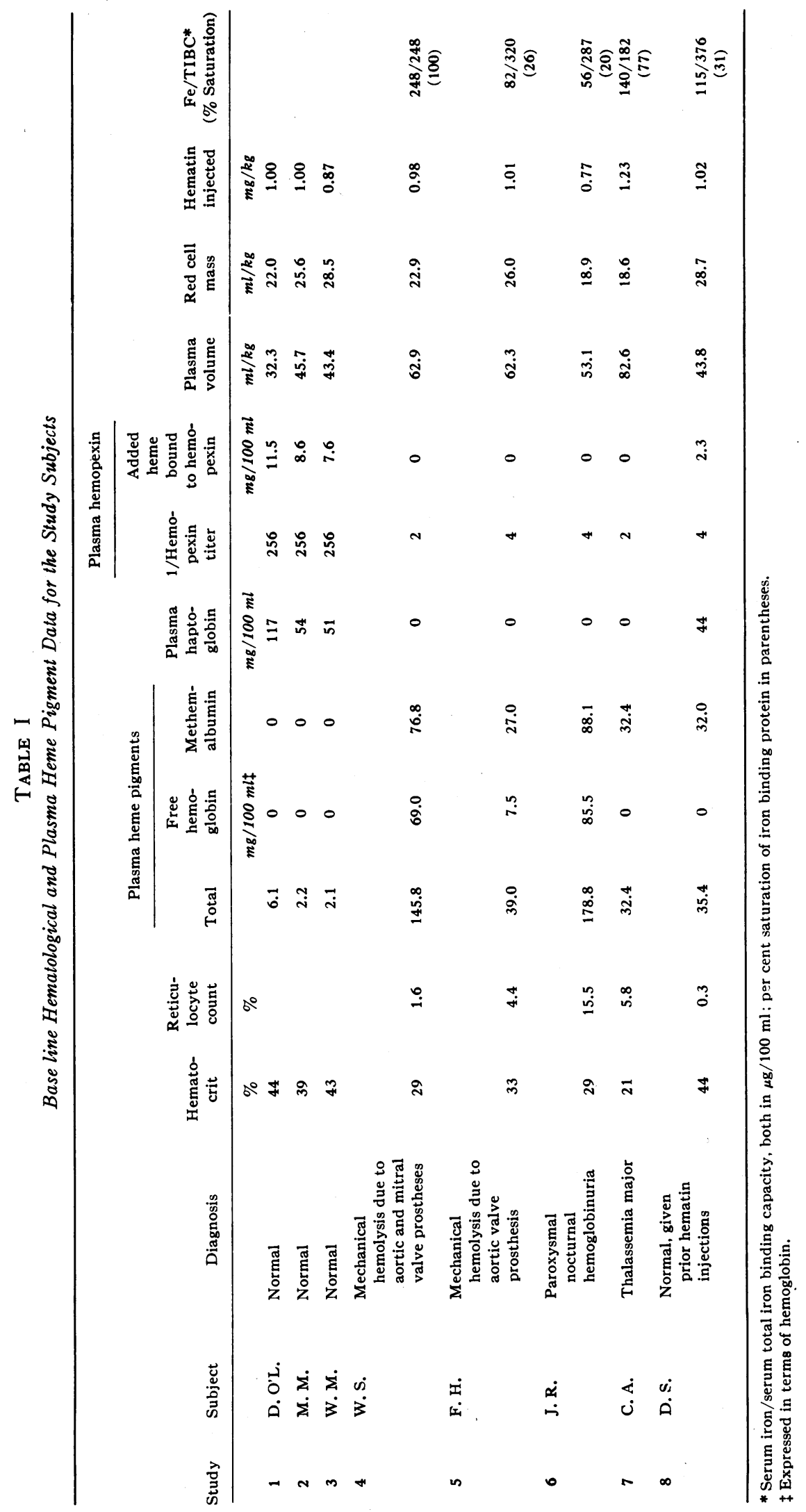




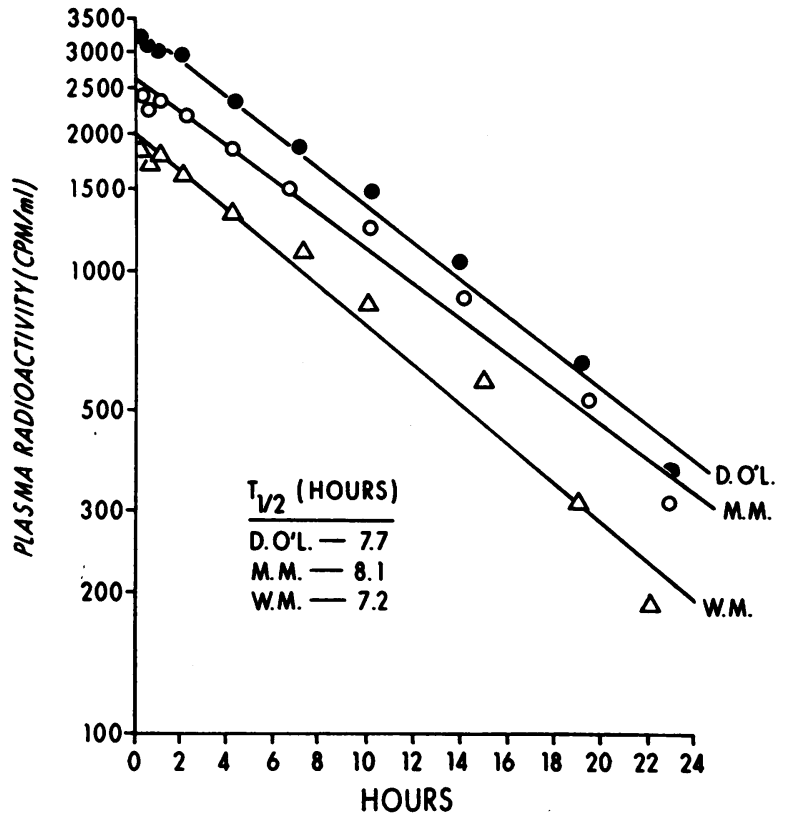

FIGURE 2 Disappearance of radioactivity from the plasma after hematin- ${ }^{50} \mathrm{Fe}$ injection in three normal subjects (studies 1-3).

counts over the heart as plasma radioactivity fell and before uptake of the isotope by red cells was detectable. There was a coincident marked rise in activity over the liver, reaching a peak about 2 days after injection. Only slight increases in activity over the spleen and sacrum were observed. When the surface counting data were plotted as ratios of liver, spleen, and sacrum

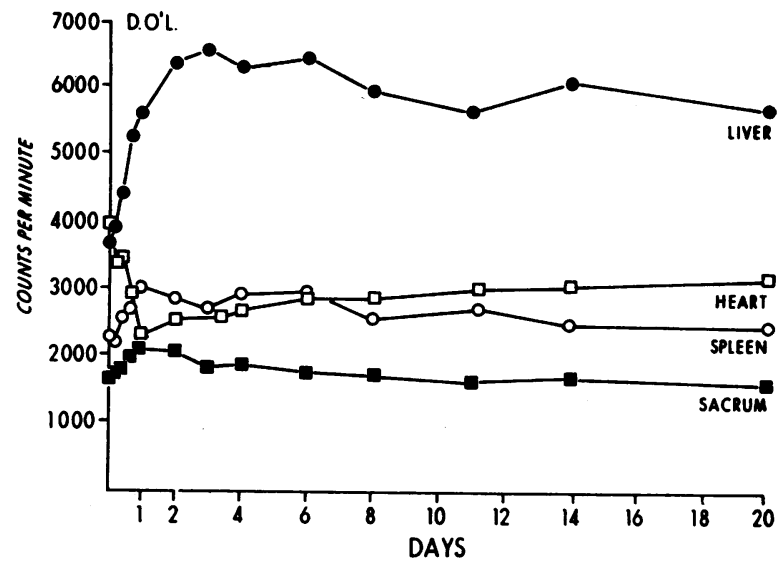

FIGURE 3 Organ radioactivity determined by body surface counting after injection of hematin- ${ }^{50} \mathrm{Fe}$ in a normal subject ( study 1).

counts to heart counts, the greatest rise was in the liver: heart ratio.

Reutilization of the heme-iron for hemoglobin synthesis is depicted in Fig. 4 which shows the time course for red cell incorporation of ${ }^{50} \mathrm{Fe}$. By 21 days after administration of hematin $-{ }^{50} \mathrm{Fe}, 26-40 \%$ of the injected isotope was in circulating erythrocytes. Red cell radioactivity was followed for over 100 days, by which time it had begun to decline in each case. Peak values for incorporation were 53,51 , and $48 \%$ of the injected isotope in studies $1-3$, respectively.

In none of the three studies was any significant depletion of plasma hemopexin detected by the two techniques employed, either during or after clearance of the

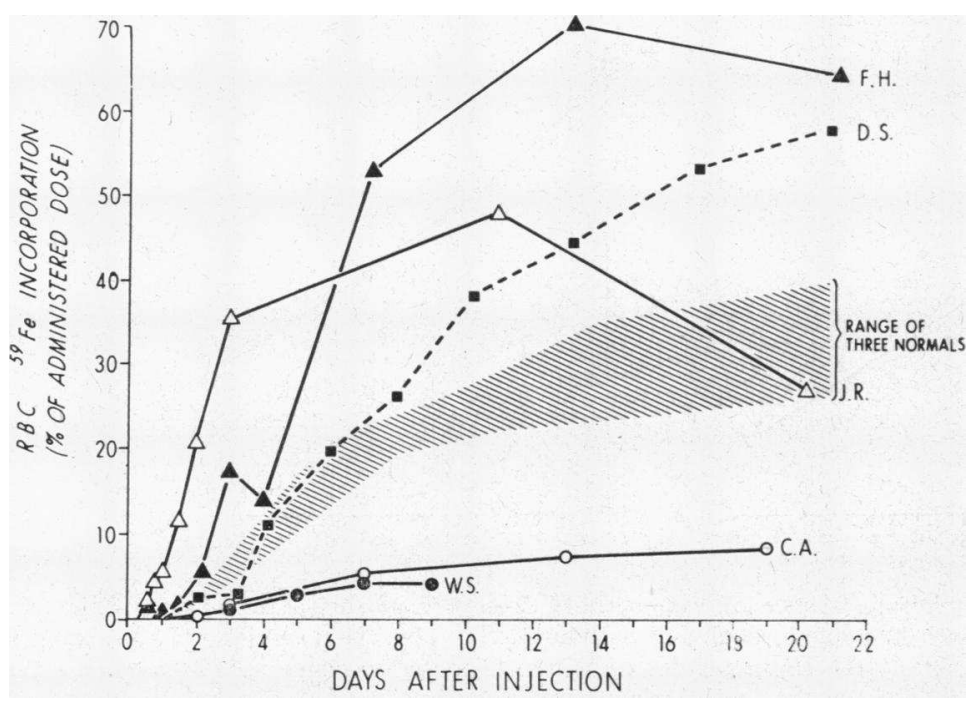

FIGURE 4 Red cell incorporation of ${ }^{\circ} \mathrm{Fe}$ after injection of hematin- ${ }^{50} \mathrm{Fe}$. The normal range shown is from studies $1-3$. 
injected hematin, nor was there any change in plasma haptoglobin levels during the course of the studies. There was no significant rise in the plasma concentration of bilirubin (total, conjugated, or unconjugated) in any of the 10 blood samples tested in the $48 \mathrm{hr}$ after hematin injection. Urines, collected for $5 \mathrm{hr}$ after injection in study $1,10 \mathrm{hr}$ in study 2 , and $7 \mathrm{hr}$ in study 3 , were free of measurable heme pigment and contained no detectable radioactivity.

Subjects with hemopexin depletion (studies 4-8). Since hemopexin was depleted in the plasma of these subjects (Table I), all injected hematin ${ }^{50} \mathrm{Fe}$ was rapidly bound to albumin. The kinetics of clearance of heme from the plasma as determined by disappearance of plasma radioactivity were different from those in the normal subjects. Computer analysis demonstrated that the data fitted an equation with two exponential terms of the form: $y=\mathrm{Ae}^{-\mathrm{k}_{1} \mathrm{t}}+\mathrm{Be}^{-\mathrm{k}_{2} \mathrm{t}}$. The data for the five studies are plotted in Fig. 5, and the computer-derived values for rate constants and intercepts are shown in Table II.

The results of body surface counting for studies 4-8 are shown in Fig. 6. In studies 4 and 7 (subjects W. S. and C. A.) there was rising activity over the liver, as in normal subjects, and no significant rise in sacral counts. In contrast, in studies 5 and 6 (subjects F. H. and J. R.) no increase in hepatic activity was seen, and in both a brief but definite rise in sacral counts occurred with its peak at 1-2 days. In study 8 (subject D. S.) counts over the liver rose early but fell again at 8-10 days, and sacral activity showed a small rise with its peak at 3 days.

${ }^{50} \mathrm{Fe}$ reutilization is shown in Fig. 4. Initial red cell incorporation of the isotope was greater and more rapid than the normal subjects in subjects F. H. and J. R. and much less than the normals in subjects W. S. and C. A. In the normal subject (D. S.) with depleted hemopexin, isotope incorporation was initially within the range ob-
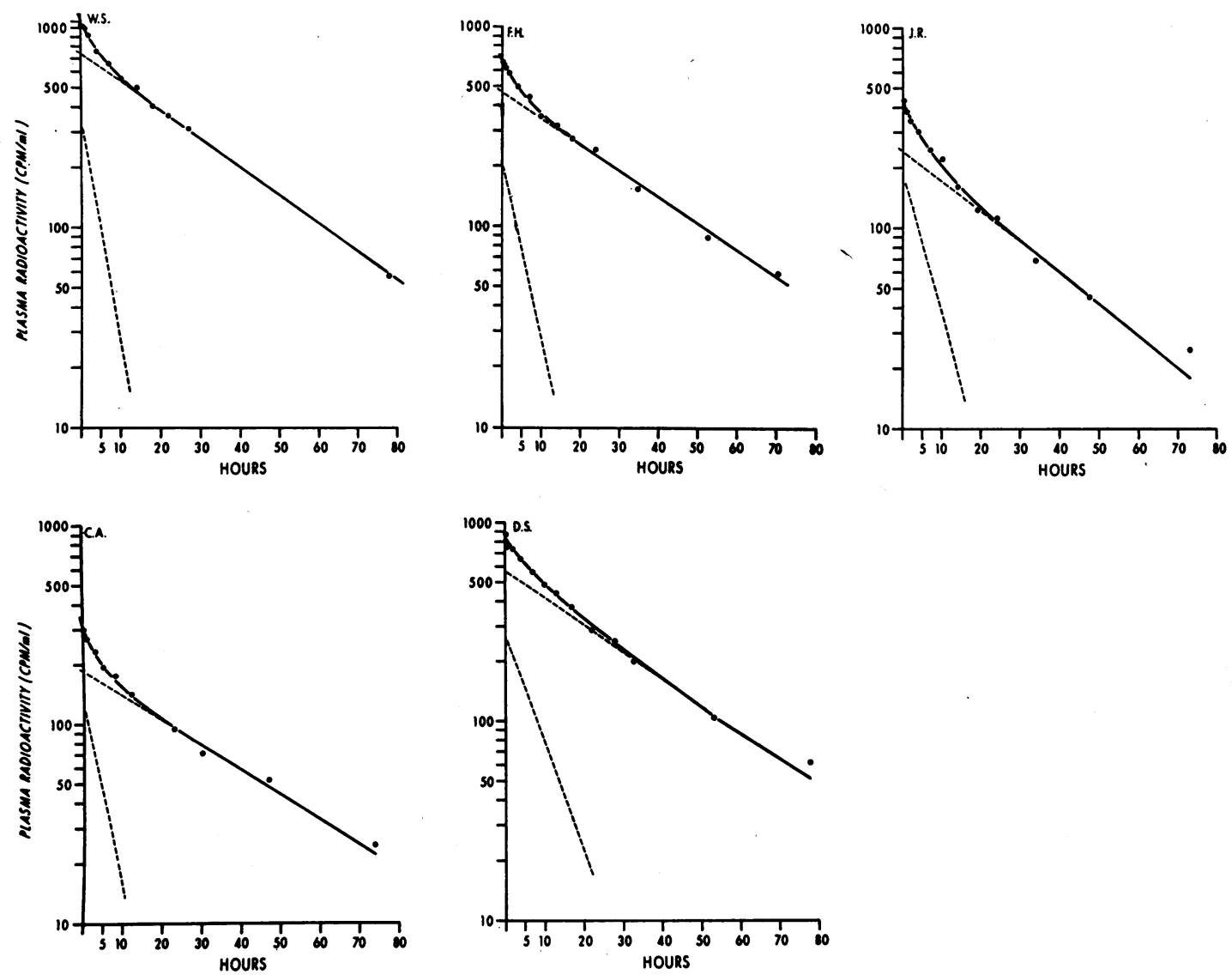

FIGURE 5 Disappearance of radioactivity from the plasma after hematin- ${ }^{50} \mathrm{Fe}$ injection in five subjects with hemopexin depletion (studies 4-8). The black circles are the experimental points.

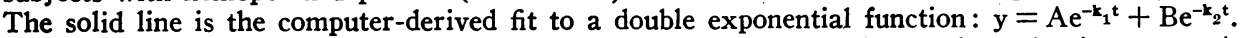
The dotted lines are the two exponential components with slopes $k_{1}$ and $k_{2}$ and $y$-intercepts $A$ and $B$, respectively. In each case the lower line is the first exponential, $y=\mathrm{Ae}^{-k_{1} t}$, and the upper line is the second, $\mathrm{y}=\mathrm{Be}^{-k_{2}} \mathrm{t}$. 
TABLE II

Clearance Rate Constants and Intercepts for Studies on Patients with Hemolytic Disease and Normal Subject with Plasma Hemopexin Depleted*

\begin{tabular}{|c|c|c|c|c|c|c|c|c|}
\hline $\begin{array}{l}\text { Study } \\
\text { No. }\end{array}$ & Subject & $k_{1}$ & $\begin{array}{c}\text { Corresponding } \\
T_{\frac{1}{2}}\end{array}$ & $\mathbf{k}_{\mathbf{2}}$ & $\underset{T}{\text { Corresponding }}$ & A & B & $\frac{A}{A+B}$ \\
\hline & & & $h r$ & & $h r$ & & & \\
\hline 4 & W. S. & $0.243 \pm 0.059$ & 2.85 & $0.032 \pm 0.004$ & 21.66 & $356 \pm 61$ & $744 \pm 65$ & 0.32 \\
\hline 5 & F. H. & $0.205 \pm 0.054$ & 3.38 & $0.030 \pm 0.003$ & 23.11 & $206 \pm 36$ & $467 \pm 38$ & 0.31 \\
\hline 6 & J. R. & $0.163 \pm 0.062$ & 4.25 & $0.035 \pm 0.009$ & 19.80 & $179 \pm 66$ & $242 \pm 68$ & 0.43 \\
\hline 7 & C. A. & $0.212 \pm 0.064$ & 3.27 & $0.029 \pm 0.004$ & 23.90 & $119 \pm 24$ & $184 \pm 25$ & 0.39 \\
\hline 8 & D. S. & $0.125 \pm 0.084$ & 5.55 & $0.031 \pm 0.009$ & 22.36 & $263 \pm 199$ & $566 \pm 204$ & 0.32 \\
\hline \multicolumn{2}{|c|}{ Mean values } & $0.190 \pm 0.046$ & $\begin{array}{l}3.86 \\
\quad \pm 1.07\end{array}$ & $0.031 \pm 0.002$ & $\begin{array}{l}22.17 \\
\quad \pm 1.56\end{array}$ & & & $\begin{array}{l}0.35 \\
\quad \pm 0.05\end{array}$ \\
\hline
\end{tabular}

* Data for the disappearance of radioactivity from the plasma after $\mathrm{Fe}^{59}$-hematin injection were analyzed by computer and fitted to the equation: $\mathrm{y}=\mathrm{Ae}^{-\mathbf{k}_{1} \mathbf{t}}+\mathrm{Be}^{-\mathbf{k}_{2} t}$. $\mathrm{k}_{1}$ and $\mathrm{k}_{\mathbf{2}}$ are the rate constants for the two components of the curve. Corresponding $T_{3}$ values are then $0.69315 / \mathrm{k}$. A and $B$ are the $y$-intercepts for the two components. The figures after the \pm sign are standard deviations. The fact that standard deviations are largest in study No. 8 may reflect the lesser degree of hemopexin depletion and/or the fact that steady-state conditions were least closely approached in that study.

served in the normal subjects but reached higher values after 6 days.

None of the subjects had a significant increase in plasma bilirubin during the period of clearance of the injected hematin.

Two of the subjects had significant hemoglobinuria. In the $24 \mathrm{hr}$ after hematin $-{ }^{50} \mathrm{Fe}$ injection, F. H. excreted $832 \mathrm{mg}$ and J. R. $2829 \mathrm{mg}$ of hemoglobin. However, in none of the studies was there significant urinary loss of the administered hematin ${ }^{50} \mathrm{Fe}$. Urine radioactivity was less than $0.5 \%$ of the administered amount in all cases.

\section{DISCUSSION}

Clearance of plasma heme in normal subjects. Though the data fitted a single exponential plot (Fig. 2), it seems unlikely that clearance is as uncomplicated as those kinetics might imply. Injected hematin was bound by both hemopexin and albumin, was exchangeable between the two proteins in vitro (10), and both hemeproteins were undoubtedily involved in its removal from the plasma. Since repeated hematin injections result in depletion of plasma hemopexin (27), the hemopexinheme complex may be removed from the plasma as a unit. That albumin-bound heme is more slowly cleared was shown by the studies here in the hemopexin-depleted subjects, and in those subjects methemalbumin clearance was not a simple first-order process. Thus, the firstorder clearance probably represents the composite result of several simultaneous processes.

Clearance of plasma heme in subjects with hemopexin depletion. The clearance kinetics for methemalbumin fitted a double exponential equation as shown in Table II and Fig. 5. The difference in kinetics and slower removal of heme in these subjects as compared with the normals is most probably related to the absence of hemopexin in the patients rather than to some other effect of their hemolytic disease. This conclusion is fortified by the results in study 8 in which the subject had hemopexin depletion without hemolysis. In a prior study on the same subject done with nonradioactive heme, the clearance, measured by chemical rather than isotopic means, was first-order, and the half-life of plasma heme $(8.3 \mathrm{hr})$ was similar to the values observed in the normal studies reported here. These data suggest that hemopexin-heme is cleared more rapidly than methemalbumin.

Methemalbumin is removed from the plasma at a considerably slower rate than other heme-proteins which have been studied. The plasma half-life of the haptoglobin-hemoglobin complex in man when studied with tracer amounts of hemoglobin has been estimated to be as short as $10-30 \mathrm{~min}(18,41)$, although $\mathrm{t}_{\mathrm{t}}$ values of $2-4$ $\mathrm{hr}$ have been reported in studies in which larger amounts of hemoglobin were administered $(16,17)$. On the basis of a few studies in man, it appears that free hemoglobin is cleared even more rapidly than the haptoglobinhemoglobin complex $(17,42)$. Similar findings have been reported in rats (43) and rabbits (44). The demonstration of relatively slow removal of methemalbumin from the plasma confirms the early studies of Fairley who detected heme-pigment spectrophotometrically for almost 2 days after intravenous injection of a large dose of hematin (5). The slow clearance relative to free hemoglobin also sheds light on observations that methemalbumin is the predominant plasma heme pigment in most patients with chronic intravascular hemolysis (7, 8). 
Barrett, Berk, Menken, and Berlin have shown that clearance of plasma unconjugated bilirubin can be described by a double exponential equation (45). The similarity between heme and bilirubin in this regard may relate to their similar structure and binding to albumin. Even the ratio of the two components of the clearance curves is similar; that is, the $t$ of the rapid component is about $15 \%$ of the $t$ of the slow component for both bilirubin and heme. However, the rate constants are quite different, so that the half-lives for heme are about 10 times longer than those for bilirubin. Also the relationship between the $y$-intercepts of the two components $(\mathrm{A} / \mathrm{A}+\mathrm{B}$, Table II) is different, averaging 0.74 in the bilirubin studies (45) and 0.35 for heme. Heme and bilirubin may be bound at the same sites on albumin (46), and a greater affinity of albumin for heme (47) may be one of the determinants of its slower removal from the circulation.

The double exponential form of the disappearance curves for heme $-{ }^{\mathrm{sp}} \mathrm{Fe}$ bound to albumin is compatible with a compartmental model involving reversible equi-
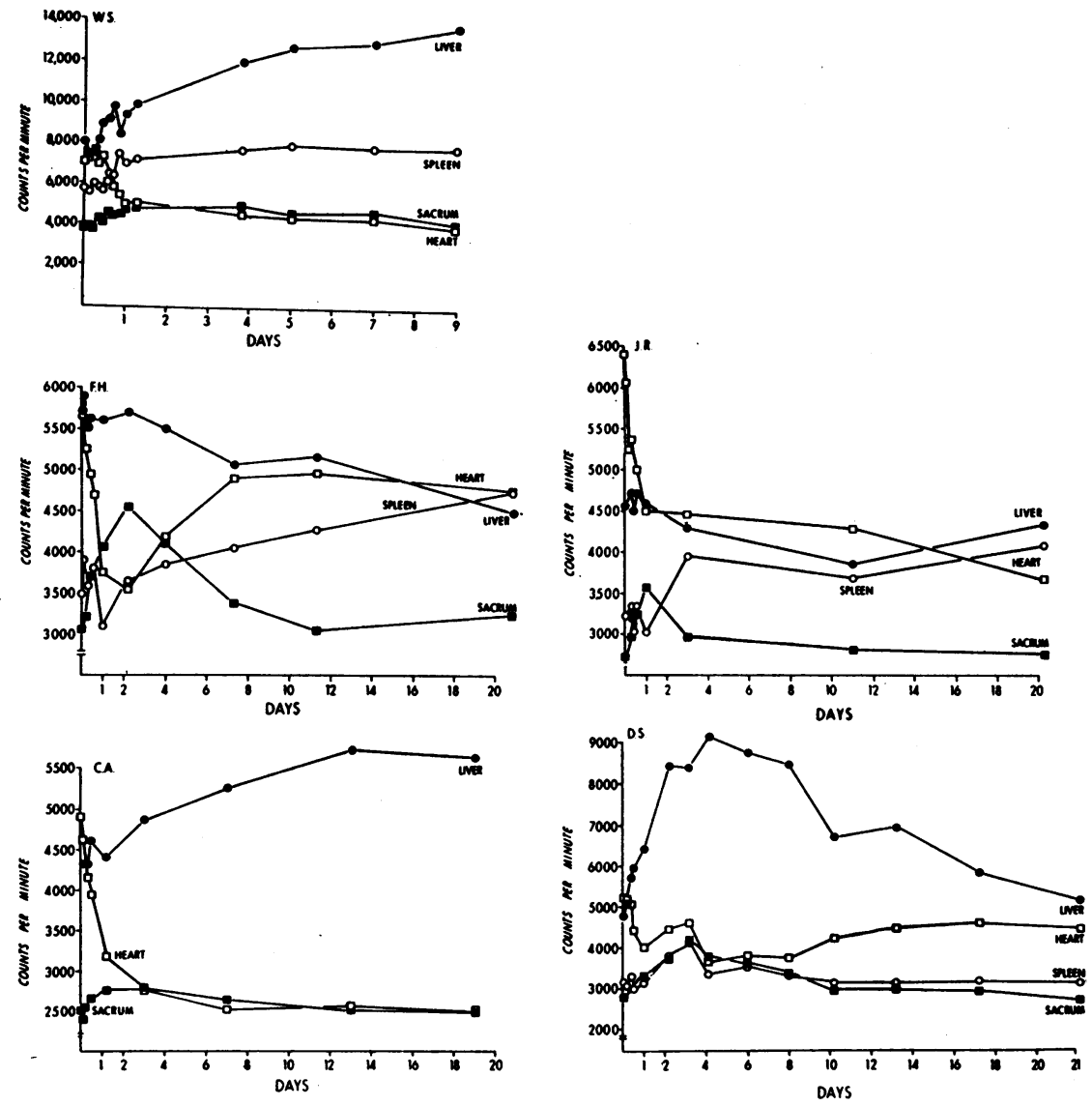

FIGURE 6 Organ radioactivity determined by body surface counting after injection of hematin- ${ }^{-5} \mathrm{Fe}$ in five subjects with hemopexin depletion. Note the difference in the time scale in the study on W. S. Subject C. A. had been splenectomized. librium between two pools with irreversible exit from one. Two such models and the data that can be derived from them, such as rate constants, pool sizes, and turnovers, have been discussed in detail by Barrett et al. (45).

Sites of removal of plasma heme. The body surface counting studies in the normal subjects as exemplified by study 1 (Fig. 3) clearly suggest that the liver was the major site of removal of heme from the plasma. Similar patterns of rapid hepatic uptake were seen in three of the hemopexin-depleted subjects (Fig. 6). The failure to observe rising activity over the liver in subjects F. H. and J. R. may have been due to the rapid reutilization of the heme-iron for hemoglobin synthesis in the marrow as reflected by the significant early peaks of radioactivity over the sacrum and by the rapid red cell uptake of the isotope (Fig. 4). Previous studies have shown that the liver is also the site of removal of protein-bound heme in animals $(21,22)$ and of free and haptoglobin-bound hemoglobin in animals $(35,43,48)$ and $\operatorname{man}(15,16)$. 
Reutilization of heme-iron (Fig. 4). In the normal subjects incorporation of the heme-iron into circulating red cells could be detected within $48 \mathrm{hr}$ after hematin injection, and a total of about $50 \%$ of the injected dose was incorporated over the ensuing 8-12 wk. The rate of reutilization of the heme-iron was somewhat slower than that observed by Garby and Noyes for hemoglobin-iron (20) and by Noyes, Bothwell, and Finch for hemoglobiniron administered as effete red cells (49).

Reutilization in the patients was quite variable and was correlated to some degree with the status of body iron metabolism as assessed by serum iron and ironbinding capacity. Subjects F. H. and J. R. had normal and slightly low levels of serum iron respectively ( $\mathrm{Ta}$ ble I), but in both the per cent saturation of serum iron-binding protein was below the normal range of 35$40 \%$, whereas in hemolytic disease the per cent saturation is usually above normal (50). Though iron stores were not evaluated directly, both patients had constant hemosiderinuria to account for a possible diminution in iron stores (8). The studies of Noyes et al. demonstrated that reutilization of red cell hemoglobin-iron was more rapid in iron-deficient subjects than in normals (49). Subjects W. S. and C. A., on the other hand, had markedly increased saturation of serum ironbinding protein due to iron loading associated with frequent transfusions in W. S. and transfusions and thalassemia in C. A. Very little of the administered heme-iron was incorporated into the red cells of these two patients over the period of study, presumably because of impaired erythropoiesis and dilution of the isotope in their excessive tissue iron stores. The reason for the rise in red cell iron incorporation after the 1 st wk in subject D. S. above that seen in the other normal subjects is not clear.

Urinary excretion of heme. There are conflicting reports in the literature as to whether methemalbum:n is (51) or is not $(5,52)$ excreted in the urine. It can be identified in the urine of some patients with intravascular hemolysis ${ }^{10}$ but could arise by the transfer of heme from methemoglobin to albumin in the urine rather than by glomerular filtration of the methemalbumin itself. The failure to find significant amounts of radioactivity in the urine after injection of hematin $-{ }^{50} \mathrm{Fe}$ in the present studies suggests that if any methemalbumin was filtered, its iron was reabsorbed.

\section{ACKNOWLEDGMENTS}

I wish to thank Dr. David A. Goldstein for carrying out the computer analyses. The able technical assistance of Donna J. Meisenzahl is gratefully acknowledged. Appreciation is expressed to Doctors P. N. Yu, A. W. Bauman, and R. F. Bakemeier for assistance in studying patients under

${ }^{10}$ Sears, D. A. Unpublished observations. their care, and to Dr. C. F. Reed for helpful discussions, and to the volunteer subjects and patients for their unstinting cooperation.

This investigation was supported by a U. S. Public Health Service General Research Support Grant, by U. S. Public Health Service Research Grant No. FR-44, from the Division of Research Facilities and Resources, $\mathrm{Na-}$ tional Institutes of Health, and by Grant No. P-509 from the American Cancer Society. The use of human volunteers was approved by the Committee on Clinical Investigation of the University of Rochester School of Medicine and Dentistry in accordance with the requirements of the U. S. Public Health Service.

\section{REFERENCES}

1. Sears, D. A. 1969. The fate of plasma heme in hemolytic disease. Clin. Res. 17: 342 .

2. Schumm, O. 1912. Hämatinämie bie toxischem Blutkörperchenzerfall. $Z$. Phys. Chem. 80: 1 .

3. Wintrobe, M. M. 1967. Clinical Hematology. Lea \& Febiger, Philadelphia. 6th edition. 167.

4. Heilmeyer, L. 1943. Medizinische Spektrophotometrie. Adams Hilger Ltd., London.

5. Fairley, N. H. 1941. Methaemalbumin. Part I. Clinical aspects. Quart. J. Med. 10: 95.

6. Fairley, N. H. 1941. Methaemalbumin. Part II. Its synthesis, chemical behaviour, and experimental produ tion in man and monkeys. Quart. J. Med. 10: 115.

7. Lathem, W., and W. N. Jensen. 1962. The renal excretion of hemoglobin in sickle cell anemia, with observations on spontaneously occurring hemoglobinemia and methemalbuminemia. J. Lab. Clin. Med. 59: 137.

8. Sears, D. A., P. R. Anderson, A. L. Foy, H. L. Williams, and W. H. Crosby. 1966. Urinary iron excretion and renal metabolism of hemoglobin in hemolytic disease. Blood. 28: 708.

9. Mollison, P. L. 1967. Blood Transfusion in Clinical Medicine. F. A. David Company, Philadelphia. 4th edition. 583 .

10. Heide, K., H. Haupt, K. Störiko, H. E. Schultze. 1964. The heme-binding capacity of hemopexin. Clin. Chim. Acta. 10: 460.

11. Muller-Eberhard, U., and H. Cleve. 1963. Immunoelectrophoretic studies of the $\beta_{1}$-haem-binding globulin (haemopexin) in hereditary haemolytic disorders. $\mathrm{Na}$ ture (London). 197: 602.

12. Hanstein, A., and U. Muller-Eberhard. 1968. Concentration of serum hemopexin in healthy children and adults and in those with a variety of hematological disorders. J. Lab. Clin. Med. 71: 232.

13. Sears, D. A. 1968. Plasma heme-binding in patients with hemolytic disorders. J. Lab. Clin. Med. 71: 484.

14. Muller-Eberhard, U., J. Javid, H. H. Liem, A. Hanstein, and M. Hanna. 1968. Plasma concentrations of hemopexin, haptoglobin, and heme in patients with various hemolytic diseases. Blood. 32: 811.

15. Jandl, J. H., M. S. Greenberg, R. H. Yonemoto, and W. B. Castle. 1956. Clinical determination of the sites of red cell sequestration in hemolytic anemias. J. Clin. Invest. 35: 842 .

16. Jandl, J. H., A. R. Jones, and W. B. Castle. 1957. The destruction of red cells by antibodies in man. I. Observations on the sequestration and lysis of red cells altered by immune mechanisms. J. Clin. Invest. 36: 1428. 
17. Lathem, W., and W. E. Worley. 1959. The distribution of extracorpuscular hemoglobin in circulating plasma. J. Clin. Invest. 38: 474.

18. Garby, L., and W. D. Noyes. 1959. Studies on hemoglobin metabolism. I. The kinetic properties of the plasma hemoglobin pool in normal man. J. Clin. Invest. 38: 1479.

19. Faulstick, D. A., J. Lowenstein, and M. J. Yiengst. 1962. Clearance kinetics of haptoglobin-hemoglobin complex in the human. Blood. 20: 65.

20. Garby, L., and W. D. Noyes. 1959. Studies on hemoglobin metabolism. II. Pathways of hemoglobin iron metabolism in normal man. J. Clin. Invest. 38: 1484.

21. Sears, D. A., and H.-J. Huser. 1966. Plasma hematinbinding and clearance in the rhesus monkey. Proc. Soc. Exp. Biol. Med. 121: 111 .

22. Snyder, A. L., and R. Schmid. 1965. The conversion of hematin to bile pigment in the rat. J. Lab. Clin. Med. 65: 817.

23. Muller-Eberhard, U., H. H. Liem, A Hanstein, and P. A. Saarinen. 1969. Studies on the disposal of intravascular heme in the rabbit. J. Lab. Clin. Med. 73: 210.

24. Hughes Jones, N: C., B. Gardner, and R. Helps. 1961. Observations on the binding of haemoglobin and haematin by serum proteins in the rabbit, rat and guinea pig. Biochem. J. 79: 220.

25. Muller-Eberhard, U., and H. H. Liem. 1968. Exchange of heme between human hemopexin, human albumin, rabbit hemopexin and rabbit albumin. Fed. Proc. $27: 723$.

26. Labbe, R. F., and G. Nishida. 1957. A new method of hemin isolation. Biochim. Biophys. Acta. 26: 437.

27. Sears, D. A. 1969. Depletion of plasma hemopexin in man by hematin injections. Proc. Soc. Exp. Biol. Med. 131: 371.

28. Crosby, W. H., and F. W. Furth. 1956. A modification of the benzidine method for measurement of hemoglobin in plasma and urine. Blood. 11: 380.

29. Hanks, G. E., M. Cassell, R. N. Ray, and H. Chaplin, Jr. 1960. Further modification of the benzidine method for measurement of hemoglobin in plasma. J. Lab. Clin. Med. 56: 486 .

30. Crosby, W. H., J. I. Munn, and F. W. Furth. 1954. Standardizing a method for clinical hemoglobinometry. U. S. Armed Forces Med. J. 5: 693.

31. Colfs, B., and J. Verheyden. 1965. A rapid method for the determination of serum haptoglobin. Clin. Chim. Acta. 12: 470.

32. Sears, D. A., and W. H. Crosby. 1965. Intravascular hemolysis due to intracardiac prosthetic devices. Amer. J. Med. 39: 341 .

33. Hosain, F., G. Marsaglia, and C. A. Finch. 1967. Blood ferrokinetics in normal man. J. Clin. Invest. 46: 1.
34. Bunn, H. F., and J. H. Jandl. 1968. Exchange of heme among hemoglobins and between hemoglobin and albumin. J. Biol. Chem. 243: 465.

35. Rabiner, S. F., J. R. Helbert, H. Lopas, and L. H. Friedman. 1967. Evaluation of a stroma-free hemoglobin solution for use as a plasma expander. J. Exp. Med. 126: 1127.

36. Wallis, W. A., and H. V. Roberts. 1956. Statistics. A New Approach. The Free Press, Glencoe. 534.

37. Whittaker, E. and G. Robinson. 1944. The Calculus of Observations. Blackie \& Son Ltd., London. 4th edition. 214.

38. Malloy, H. T., and K. A. Evelyn. 1937. The determination of bilirubin with the photoelectric colorimeter. $J$. Biol. Chem. 119: 481.

39. Young, D. S., and J. M. Hicks. 1965. Method for the automatic determination of serum iron. J. Clin. Pathol. 18: 98.

40. Dacie, J. V., and S. M. Lewis. 1963. Practical Haematology. J. \& A. Churchill Ltd., London. 3rd edition.

41. Freeman, T. 1964. Haptoglobin metabolism in relation to red cell destruction. Protides Biol. Fluids Proc. Colloq. Bruges. 12: 344.

42. Andersen, M. N., C. V. Mouritzen, and E. Gabrieli. 1966. Mechanisms of plasma hemoglobin clearance after acute hemolysis: studies in open-heart surgical patients. Ann. Surg. 163: 529.

43. Keene, W. R., and J. H. Jandl. 1965. The sites of hemoglobin catabolism. Blood. 26: 705.

44. Murray, R. K., G. E. Connell, and J. H. Pert. 1961. The role of haptoglobin in the clearance and distribution of extracorpuscular hemoglobin. Blood. 17: 45.

45. Barrett, P. V. D., P. D. Berk, M. Menken, and N. I. Berlin. 1968. Bilirubin turnover studies in normal and pathologic states using bilirubin- ${ }^{14} \mathrm{C}$. Ann. Intern. Med. 68: 355.

46. Odell, G. B. 1959. The dissociation of bilirubin from albumin and its clinical implications. J. Pediat. 55: 268.

47. Dossett, J., and H. P. Bentley, Jr. 1963. Protein binding of hematin in the newborn. Amer. J. Dis. Child. 105: 27.

48. Garby, L., and J. Obara. 1960. Organ uptake and plasma transportation kinetics of hemoglobin in rats. Blut. 6: 143.

49. Noyes, W. D., T. H. Bothwell, and C. A. Finch. 1960. The role of the reticulo-endothelial cell in iron metabolism. Brit. J. Haematol. 6: 43.

50. Bothwell, T. H., and C. A. Finch. 1962. Iron Metabolism. Little, Brown Co. Inc., Boston. 164.

51. Hensley, W. J., and C. R. B. Blackburn. 1953. Methemalbumin in the urine. Aust. J. Sci. 16: 64.

52. Crosby, W. H. 1955. The metabolism of hemoglobin and bile pigment in hemolytic disease. Amer. J. Med. 18: 112. 